\begin{tabular}{|c|c|c|c|c|}
\hline $\begin{array}{c}\text { Prosiding Penelitian \& } \\
\begin{array}{c}\text { Pengabdian Kepada } \\
\text { Masyarakat }\end{array}\end{array}$ & $\begin{array}{c}\text { e ISSN : 2581-1126 } \\
\text { p ISSN : 2442-448X }\end{array}$ & Vol 7, No: 1 & Hal: $90-99$ & April 2020 \\
\hline
\end{tabular}

\title{
Pengaruh Perkawinan Muda terhadap Ketahanan Keluarga
}

\author{
Farah Tri Apriliani ${ }^{1}$, Nunung Nurwati ${ }^{2}$ \\ 1Mahasiswa J urusan IImu Kesejahteraan Sosial FISI P Universitas Padjadjaran, ²Dosen \\ Program Studi I Imu Kesejahteraan Sosial FISIP Universitas Padjadjaran \\ ${ }^{1}$ farah18005@mail.unpad.ac.id, 2nngnunwati@yahoo.co.id
}

\begin{abstract}
ABSTRAK
Perkawinan usia muda menjadi salah satu permasalahan yang terus terjadi di Indonesia sampai hari ini meskipun angka atau tingkat perkawinan usia muda tidak tinggi akan tetapi terus meningkat disetiap tahunnya. Sehingga, kesiapan dalam menikah masih belum matang, kondisi emosi yang belum stabil bisa mengakibatkan kepada ketahanan serta kualitas keluarga yang akan dibangun. Tentunya, perkawinan muda akan berpengaruh terhadap ketahanan keluarga, sebab ketika mereka memutuskan untuk kawin muda sudah pasti akan berhenti sekolah yang pada akhirnya menyebabkan minimnya pengetahuan yang terbatas. Tujuan dari penulisan ini adalah untuk memberikan edukasi mengenai keterkaitan antara perkawinan muda dengan ketahanan keluarga, menjelaskan seperti apa pengaruh yang akan diberikan. Penulisan ini menggunakan metode penelitian kualitatif dengan jenis penelitian studi kepustakaan dan menggunakan sumber data sekunder.
\end{abstract}

Kata kunci: pernikahan muda, pernikahan, ketahanan keluarga

\section{ABSTRACT}

Early marriage into one of the problems that continue to occur in Indonesia to this day even though the numbers or the rate of child marriage is not high but continue to increase every year. Thus, readiness in marriage is still immature, unstable emotional conditions can lead to the resilience and quality of the family to be built. Of course, young marriages will affect family resilience, because when they decide to marry young, they will definitely quit school, which in turn will lead to a lack of limited knowledge. The purpose of this paper is to provide education about the relationship between young marriages and family resilience, explaining what kind of influence will be given. This writing uses qualitative research methods with the type of literature study research and uses secondary data sources.

Key words: early marriage, marriage, family resilience

\section{Pendahuluan}

Perkawinan menjadi salah satu gerbang utama bagi seseorang yang sudah mulai beranjak dewasa untuk membangun kehidupan baru yang lebih mandiri lagi. Menurut Undang-Undang nomor 1 tahun 1974 perkawinan adalah ikatan lahir batin antara seorang pria dengan seorang wanita sebagai suami istri dengan tujuan membentuk keluarga atau rumah tangga yang bahagia dan kekal berdasarkan Ketuhanan Yang Maha Esa. Tentunya perkawinan ini dilakukan secara hukum yang telah dipercayai oleh kedua bela pihak. Perkawinan diperbolehkan apabila kedua belah pihak atau laki-laki dan perempuan telah berusia 19 tahun berdasarkan undang-undang yang telah disepakati dalam UU 16 tahun 2009 atas perubahan UU 1 tahun 1974.
Berdasarkan data child marriage report, jika dilihat dari daerah tempat tingal menunjukkan bahwa prevalensi perkawinan anak perempuan lebih tinggi di perdesaan dibandingkan perkotaan, baik itu usia sebelum 18 tahun maupun sebelum usia 15 tahun. Pada tahun 2018, prevalensi perempuan 20-24 tahun di perdesaan yang melakukan perkawinan pertamanya sebelum usia 18 tahun masih lebih tinggi perdesaan yaitu sebesar $16,87 \%$ dan perkotaan sebesar $7,15 \%$. Sedangkan untuk anak laki-laki, sekitar 1 dari 100 laki-laki 20-24 tahun pada tahun 2018 telah melangsungkan perkawinan sebelum usia 18 tahun. Sama seperti anak perempuan yang telah melakukan perkawinan pertama, daerah perdesaan juga memiliki prevalensi yang tinggi untuk anak laki-laki yang telah melakukan perkawinan pertamanya yaitu sebesar $1,44 \%$ dan 


\begin{tabular}{|c|c|c|c|c|}
\hline $\begin{array}{c}\text { Prosiding Penelitian \& } \\
\begin{array}{c}\text { Pengabdian Kepada } \\
\text { Masyarakat }\end{array}\end{array}$ & $\begin{array}{c}\text { e ISSN : 2581-1126 } \\
\text { p ISSN : 2442-448X }\end{array}$ & Vol 7, No: 1 & Hal: $90-99$ & April 2020 \\
\hline
\end{tabular}

perkotaan adalah 0,77\%. (Sahrizal, Handayani, Chamami, \& dkk, 2020)

Beberapa alasan terjadinya perkawinan usia muda di I ndonesia ini adalah status sosial dan ekonomi yang rendah, adanya budaya kawin usia muda, perkawinan yang dipaksa dan seks bebas (BKKBN, 2012). Perkawinan usia muda ini juga difaktori oleh perjodohan, agama, tuntutan keluarga, tekanan sosial, kemauan sendiri dan pendidikan. Adanya persepsi bahwa menikah muda dapat melepaskan beban dan masalah juga dapat menjadi salah satu faktornya.

Dampak dari segi fisik, psikologis dan sosial tentu akan dirasakan oleh seseorang yang melakukan perkawinan diusia muda misalnya kebutuhan sehari-harinya tidak terpenuhi, belum adanya kesiapan untuk membangun rumah tangga sehingga belum adanya pengetahuan untuk menjadi seorang ayah dan ibu, dan lingkungan yang belum tentu bisa menerimanya sebagai akibat perkawinan yang tidak diinginkan (married by accident).

Resiko lain dari perkawinan muda adalah terjadinya KDRT, resiko ketika melahirkan karena alat reproduksi pada usia muda belum berkembang dengan baik, yang nantinya akan berdampak pada kematian ibu atau bayi. Perkawinan usia muda juga akan mengakibatkan ketidaksiapan dalam membangun rumah tangga, karena mereka belum cukup dewasa dalam bersikap maupun dalam pengambilan keputusan.

Menurut penelitian plan (dalam Djamilah 2014), menjelaskan bahwa perkawinan muda sangat rentan terjadinya Kekerasan Dalam Rumah Tangga (KDRT). Sebanyak 44\% anak perempuan yang melakukan pernikahan ini mengalami KDRT dengan tingkat frekuensi tinggi, sisanya 56\% anak perempuan mengalami KDRT frekuensi rendah. Data tersebut menunjukkan bahwa hasil dari perkawinan muda menjadikan tidak siapnya pasangan suami istri dalam membangun keluarga.

Sehingga ketahanan keluarga dapat terganggu. Ketahanan keluarga atau resiliensi keluarga menurut Peraturan Pemerintah Republik Indonesia Nomor 21 Tahun 1994 (dalam Cahyaningtyas, Tenrisana dan Triana, 2016) adalah

"Sebagai suatu kondisi dinamik keluarga yang memiliki keuletan, ketangguhan dan kemampuan fisik, materil dan mental untuk hidup secara mandiri".
Maka, jika merujuk pada data mengenai KDRT dapat disimpulkan bahwa ketahanan keluarga belum bisa dicapai sebagai akibat dari minimnya pendidikan. Sementara dalam sebuah keluarga kemampuan resiliensi diperlukan untuk mengatasi dan menyesuaikan diri pada perubahan yang sulit terjadi dalam hidup atau permasalahan yang berat.

Teori yang akan digunakan dalam penelitian ini adalah teori struktural fungsional yang menekankan pada stabilitas kehidupan sosial. Dalam teori ini menjelaskan bahwa aspek penting dari struktural fungsionalis adalah terdapat pembagian peran/fungsi keluarga yang jelas, dengan terpola dalam struktur hirarkis yang harmonis berlandaskan komitmen terhadap pelaksanaan peran/fungsi tersebut. Teori ini menjelaskan bahwa tiap-tiap anggota keluarga harus menjalani hidupnya sesuai dengan perannya. Teori ini merujuk pada ketahanan keluarga yang dihasilkan dari perkawinan muda sebagai dasar untuk menganalisis kesesuaian peran yang dijalani.

Data-data diatas mengenai tingkat perkawinan muda di Indonesia dan juga tingat KDRT pada perkawinan muda kiranya sudah cukup menjelaskan bahwa masih ketahanan keluarga dari perkawinan muda ini belum terciptakan. Belum adanya kemampuan resiliensi sebagai akibat dari minimnya pengetahuan yang dimiliki. Maka, tujuan dari penulisan ini adalah untuk memberikan edukasi serta informasi mengenai gambaran dari ketahanan keluarga yang terjadi pada seseorang yang melakukan perkawinan muda.

\section{Metode Penelitian}

Metode yang digunakan adalah metode penelitian kualitatif dimana metode ini merupakan metode ini sukar diukur dengan angka, bersifat deskriptif dan cenderung menggunakan analisis. Menurut Moleong (2003):

"Penelitian kualitatif merupakan penelitian yang bermaksud untuk memahami fenomena tentang apa yang dialami oleh subjek penelitian, misalnya perilaku, persepsi, motivasi, tindakan, dll secara holistic, dan dengan cara deskripsi dalam bentuk kata-kata dan bahasa, pada suatu konteks khusus yang alamiah dan dengan memanfaatkan berbagai metode alamiah."

Pada penelitian kualitatif ini nantinya penulis akan membuat suatu gambaran kompleks, meneliti sebuah kata, dan melakukan studi pada situasi yang dialami. 


\begin{tabular}{|c|c|c|c|c|}
\hline $\begin{array}{c}\text { Prosiding Penelitian \& } \\
\begin{array}{c}\text { Pengabdian Kepada } \\
\text { Masyarakat }\end{array}\end{array}$ & $\begin{array}{c}\text { e ISSN : 2581-1126 } \\
\text { p ISSN : 2442-448X }\end{array}$ & Vol 7, No: 1 & Hal: $90-99$ & April 2020 \\
\hline
\end{tabular}

Jenis penelitian ini merupakan penelitian yang berbasis studi kepustakaan ( library research). Studi kepustakaan merupakan suatu studi yang digunakan dalam mengumpulkan indormasi dan data dengan bantuan berbagai macam materi yang ada di perpustakan seperti dokumen, buku, majalah, kisah-kisah sejarah, dsb. Studi kepustakaan ini juga dapat mempelajari berbagai referensi serta hasil penelitian sebelumnya yang sejenis yang berguna untuk mendapatkan landasan teori yang akan diteliti. Dalam studi kepustakaan ini teknik pengumpulan yang dihimpun dengan melakukan penelaahan terhadap laporan yang berkitan dengan masalah yang ingin dipecahkan.

Dengan penelitian kepustakaan ini, akan melatih seorang peneliti untuk membaca secara kritis segala bahan yang didapatkan, kecermatan, dan ketelitian seorang peneliti. Oleh karena itu, dalam penelitian ini, data-data yang akan diperoleh berasal dari literatur, jurnal, buku, dan hasil penelitian yang sudah dipublikasikan sebelumnya.

Penelitian yang akan dilakukan, mencari data dan juga informasi mengenai perkawinan usia muda yang tidak sesuai dengan undang-undang atau dibawah 19 tahun terkait dengan bagaimana pengaruh terhadap ketahanan keluarganya.

\section{Sumber Data}

Sumber data yang digunakan adalah data sekunder dimana data yang diperoleh peneliti bukan berasal dari tangan pertama, melainkan tangan kedua, ketiga, dan seterusnya. Maka, dalam hal ini peneliti tidak terlibat langsung dalam proses pengamatan atau observasi, akan tetapi data diperoleh dari media massa, jurnal, artikel, data hasil penelitian lain, penelitian kepustakaan untuk mengetahui berbagai pengetahuan dan data.

Dalam penulisan ini, data diperoleh dari jurnal yang berkaitan dengan perkawinan muda, tingkat perceraian akibat dari perkawinan usia muda, konsep ketahanan keluarga, faktor penyebab perceraian dan faktor penyebab perkawinan usia muda. Selain itu, penulis juga memperoleh data yang berkaitan dengan angka perkawinan muda di Indonesia berasal dari jurnal, child marriage report yang diinisiasikan oleh UNICEF, Kementrian Pemberdayaan Perempuan dan Perlindungan Anak, BPS, dan BKKBN. Sedangkan data mengenai ketahanan keluarga, didapatkan dari jurnal, artikel, buku pengembangan ketahanan. Selain dari jurnal, buku, artikel dan laporan penulis juga memperoleh data dari berbagai website yang dapat mendukung pembahasan.

\section{Perkawinan Muda}

Fenomena perkawinan muda masih sering dijumpai di beberapa negara berkembang khususnya Indonesia. Perkawinan disebut sebagai perkawinan muda ketika dilakukan oleh seseorang yang masih dibawah umur atau anak-anak. Perkawinan muda di Indonesia ini sudah menjadi fenomena nasional, faktor yang mempengaruhi salah satunya adalah budaya karena memiliki pengaruh besar dalam pola kehidupan di masyarakat, termasuk perkawinan dibawah umur. Perkawinan usia dini adalah pernikahan yang dilaksanakan secara resmi atau tidak resmi yang dilakukan sebelum usia 18 tahun (UNI CEF, 2014).

Perkawinan muda atau perkawinan dini menjadi salah satu praktik tradisional yang sudah lama dikenal dan tersebar luas di seluruh dunia. Secara definisi, perkawinan muda sebagai ikatan lahir batin antara seorang pria dan wanita sebagai sepasang suami istri pada usia muda/remaja. Menurut World Health Organization (dalam Hanum\&Tukiman, 2015):

"Pernikahan dini atau kawin muda sendiri adalah pernikahan yang dilakukan oleh pasangan atau salah satu pasangannya masih dikategorikan sebagai remaja yang berusia dibawah 19 tahun."

Perkawinan usia muda berarti merupakan perkawinan remaja yang dilihat dari segi umur masih belum mencukupi dimana dalam UU Nomor 16 tahun 2006 telah ditetapkan umur maksimun pernikahan muda baik laki-laki maupun perempuan adalah 19 tahun.

J ika merujuk pada segi kesehatan, BkkbN (dalam Hanum\&Tukiman, 2015) menyebutkan bahwa perkawinan muda yang ideal adalah perempuan yang telah berusia diatas 20 tahun, hal ini berdasarkan pertimbangan dari kesehatan reproduksinya. Perkawinan yang dilakukan dibawah umur 20 tahun akan menyebabkan terkena kanker leher rahim, sel-sel rahim yang belum matang, dan beresiko terkena penyakit Human Papiloma Virus (HIV).

Sebuah penelitian menyatakan bahwa sebagian besar perempuan di Indonesia yang telah melakukan perkawinan dibawah umur menyadari bahwa mereka telah melakukan perkawinan terlalu dini, akan tetapi mereka melakukan perkawinan ini atas dasar keinginan orang tuanya. Tentu ada 


\begin{tabular}{|c|c|c|c|c|}
\hline $\begin{array}{c}\text { Prosiding Penelitian \& } \\
\begin{array}{c}\text { Pengabdian Kepada } \\
\text { Masyarakat }\end{array}\end{array}$ & $\begin{array}{c}\text { e ISSN : 2581-1126 } \\
\text { p ISSN : 2442-448X }\end{array}$ & Vol 7, No: 1 & Hal: $90-99$ & April 2020 \\
\hline
\end{tabular}

faktor-faktor yang mempengaruhi perkawinan muda ini terjadi di indonesia, diantaranya:

\section{a. Faktor Ekonomi}

Perkawinan muda bisa terjadi karena ekonomi yang rendah di keluarganya. Misalnya, orang tua sudah tidak sanggup mencukupi kebutuhan anaknya sehingga menyebabkan kemiskinan. Hal ini yang akhirnya menyebabkan orang tua memutuskan untuk menikahkan anaknya, karena mereka beranggapan bahwa dengan menikahkan anaknya bisa lepas dari tanggung jawab untuk membiayai kehidupan anaknya ataupun dengan harapan juga bahwa anaknya bisa mendapatkan kehidupan yang lebih baik.

Realitanya, hal inilah yang menyebabkan seorang wanita berpendidikan rendah, karena mengikuti pilihan orang tuanya untuk menikah usia dini sebagai akibat keterbatasan biaya dari orang tuanya yang tidak mampu.

\section{b. Faktor Pendidikan}

Pendidikan yang rendah tentu saja menjadi salah satu faktor yang mempengaruhi terjadinya perkawinan usia muda ini, karena pendidikan akan mempengaruhi pola pikir seseorang baik dari masyarakat sekitar, pendidikan orang tua maupun anak sendiri. Jika lingkungan sekitarnya memiliki pendidikan yang rendah, maka kecenderungan untuk mengawinkan lebih tinggi. Apabila, pendidikan yang dimiliki tinggi maka tentunya mereka akan berpikir kembali untuk melakukan pekawinan. Meninjau dari berbagai perspektif tentang bagaimana faktornya, apa yang yang akan terjadi ke depannya, dan lain-lain.

Selain itu, pendidikan yang rendah bagi seorang wanita inilah yang menyebabkan seorang wanita untuk melakukan perkawinan dini. Ini terjadi karena mereka tidak mengetahui betul bagaimana seluk beluk perkawinan sehingga akan cenderung lebih cepat untuk berkeluarga dan melahirkan anak. Tingkat pendidikan akan mempengaruhi kematangan pribadi seseorang, karena jika mereka menuntut pendidikan dengan baik, tentunya akan lebih mudah untuk menyaring dan menerima suatu perubahan yang baik dan merespon lingkungan yang dapat mempengaruhi kemampuan berpikir mereka.

\section{c. Faktor Pengetahuan}

Pengetahuan menurut Kamus Besar Bahasa Indonesia (KBBI) adalah segala sesuatu yang diketahui, dimana hal ini berhubungan dengan kepandaian seseorang. Sehingga dalam perkawinan muda ini, faktor pengetahuan sangat mempengaruhi untuk seseorang yang melakukannya karena dengan adanya pengetahuan maka mereka dapat memahami makna dari perkawinan. Khususnya perkawinan diusia muda.

Pengetahuan yang rendah menyebabkan terjadinya perkawinan usia muda karena belum adanya edukasi mengenai bahayanya melakukan perkawinan muda dan kesiapan dalam membangun rumah tangga. Faktor pengetahuan ini juga bisa berasal dari keluarganya sendiri atau orang tua, karena biasanya orang tua mendidik anak berdasarkan dengan pengetahuan yang mereka pahami.

Pengetahuan perempuan yang melakukan perkawinan diusia muda juga dipengaruhi oleh orang tua. Ketika seseorang melakukan perkawinan muda, orang tua sangat memiliki peranan penting terhadap kejadian perkawinan diusia muda. Penelitian yang dilakukan oleh Juspin (2012) menyebutkan bahwa peran orang tua sangat besar dalam pembuatan keputusan. Hal tersebut dikarenakan keputusan yang diambil berdasarkan dengan pengetahuan yang dimiliki oleh orang tuanya.

Kecenderungan perkawinan usia muda dipengaruhi oleh tingkat pendidikan dan pengetahuannya yang rendah pada seseorang yang melakukannya. Beberapa penelitian yang dilakukan juga menjelaskan bahwa perempuan yang mempunyai pengetahuan yang rendah akan beresiko untuk melakukan perkawinan diusia muda daripada perempuan yang memiliki pengetahuan tinggi.

\section{d. Faktor Pergaulan Bebas}

Perkawinan diusia muda terjadi karena kurangnya bimbingan dan perhatian dari orang tuanya, sehingga seorang anak akan mencari jalan sendiri untuk menemukan kebahagiaannya. Sehingga faktor pergaulan bebas ini bisa terjadi, mereka akan bergaul dengan semua orang tanpa dilihat latar belakangnya atau kelakuannya sehari-hari. Adanya pergaulan bebas ini yang bisa 


\begin{tabular}{|c|c|c|c|c|}
\hline $\begin{array}{c}\text { Prosiding Penelitian \& } \\
\begin{array}{c}\text { Pengabdian Kepada } \\
\text { Masyarakat }\end{array}\end{array}$ & $\begin{array}{c}\text { e ISSN : 2581-1126 } \\
\text { p ISSN : 2442-448X }\end{array}$ & Vol 7, No: 1 & Hal: $90-99$ & April 2020 \\
\hline
\end{tabular}

menyebabkan perkawinan diusia muda, karena terjadi kehamilan sebelum menikah. Sehingga, mau tidak mau ia memutuskan untuk melakukan perkawinan diusia muda.

Menurut Al-Mighwar (2006):

"Suasana keluarga yang tenang dan penuh curahan kasih sayang dari orang-orang dewaa yang ada disekelilingnya, akan menjadikan remaja dapat berkembang secara wajar dan mencapai kebahagiaan. Sedangkan suasana rumah tangga yang penuh konflik akan berpengaruh negatif terhadap kepribadian dan kebahagiaan remaja yang pada akhirnya mereka melampiaskan perasaannya daam berbagai pergaulan dan perilaku yang menyimpang."

\section{e. Faktor Budaya atau Adat Istiadat}

Perkawinan usia muda yang terjadi di Indonesia terkadang sangat erat kaitannya dengan adat-istiadatnya. Misalnya perjodohan yang dilakukan oleh orang tuanya sejak kecil. Beberapa daerah khususnya perdesaan menerapkan hal ini dikarenakan takut anaknya menjadi perawan tua, hingga pada akhirnya mereka menikahkan anaknya ketika sudah mengalami masa menstruasi yaitu sekitar umur 12 tahun.

Perjodohan ini dilakukan oleh orang tuanya untuk segera meralisasikan ikatan hubungan kekeluargaan antara kerabat mempelai laki-laki dan kerabat mempelai perempuan yang memang telah diinginkan untuk hidup bersama, agar hubungan kekeluargaan mereka tidak putus.

\section{Ketahanan Keluarga}

Pada dasarnya seseorang yang sudah memiliki keluarga pasti menginginkan keluarga yang bisa menghadapi segala situasi yang terjadi dalam kehidupan. Oleh karena itu, perlu adanya ketahanan keluarga untuk mencapai hal tersebut. Pentingnya ketahanan keluarga tertera dalam Undang-Undang Nomor 52 Tahun 2009 yang menjelaskan bahwa kondisi dinamik suatu keluarga yang memiliki keuletan dan ketangguhan serta mengandung kemampuan fisik-materiil dan psikis-mental spiritual guna hidup mandiri dan mengembangkan diri dan keluarganya untuk hidup harmonis dalam meningkatkan kesejahteraan lahir dan kebahagiaan batin (Sunarti, 2018).
Konsep ketahanan keluarga menjelaskan bahwa ketahanan keluarga dikaji berdasarkan permasalahan dan kesukaran yang dilalui oleh keluarga. Rolland dan Walsh (2005) menyampaikan bahwa jika dalam ketahanan keluarga memiliki penyakit kronis atau cacat justru dapat ditingkatkan dengan memanfaatkan waktu untuk memperdalam hubungan dengan orang terkasih. (Cahyaningtyas, Tenrisana, \& Triana, 2016)

Menurut Frankenberger (dalam Cahyaningtyas, Tenrisana dan Triana, 2016):

"Ketahanan keluarga (family strength atau family resilience) adalah kondisi kecukupan dan kesinambungan akses terhadap pendapatan dan sumber daya untuk memenuhi berbagai kebutuhan dasar antara lain: pangan, air bersih, pelayanan kesehatan, kesempatan pendidikan, perumahan, waktu untuk berpartisipasi di masyarakat dan integrasi sosial."

Dari penjelasan tersebut berarti bahwa ketahanan keluarga merupakan sebuah kondisi stabil yang dapat diciptakan oleh sebuah keluarga. Artinya, dalam kehidupan sehari-hari semua kebutuhan dasar dapat terpenuhi dengan baik tanpa adanya kekurangan.

Ketahanan keluarga juga berarti kemampuan keluarga untuk melindungi diri dari berbagai permasalahan dan ancaman yang dapat mengganggu keutuhan keluarga. Dalam membangun ketahanan keluarga ada 3 faktor laten, yaitu ketahanan fisik-ekonomi, ketahanan sosial, dan ketahanan psikologis. Selain itu terdapat 5 indikasi yang menggambarkan tingkat ketahanan keluarga diantaranya; 1) adanya sikap saling melayani sebagai tanda kemuliaan; 2) adanya keakraban antara suami dan istri menuju kualitas perkawinan yang baik; 3) adanya orang tua yang mengajar dan melatih anak-anaknya dengan berbagai tantangan kreatif, pelatihan yang konsisten dan mengembangkan keterampilan; 4) adanya suami dan istri yang memimpin seluruh anggora keluarganya dengan penuh kasih sayang; dan 5) adanya anak-anak yang menaati dan menghormati orang tuanya. (Cahyaningtyas, Tenrisana, \& Triana, 2016)

Ketahanan keluarga ini mengandung aspek yang bertujuan untuk pengembangan individu didalam keluarga maupun keluarga secara keseluruhan. Lebih luasnya, ketahanan keluarga bisa disebut sebagai ketahanan sosial karena keluarga merupakan unit terkecil dalam sistem 


\begin{tabular}{|c|c|c|c|c|}
\hline $\begin{array}{c}\text { Prosiding Penelitian \& } \\
\begin{array}{c}\text { Pengabdian Kepada } \\
\text { Masyarakat }\end{array}\end{array}$ & $\begin{array}{c}\text { e ISSN : 2581-1126 } \\
\text { p ISSN : 2442-448X }\end{array}$ & Vol 7, No: 1 & Hal: $90-99$ & April 2020 \\
\hline
\end{tabular}

sosial. Lingkup ketahanan keluarga itu sendiri mencakup seluruh aspek mengenai pemenuhan peran, fungsi, tugas keluarga dan bagaimana keluarga berinteraksi.

Berdasarkan Undang-Undang Nomor 52 tahun 2009, ketahanan keluarga dapat diukur dengan menggunakan pendekatan sistem yang didalamnya meliputi sumber daya fisik dan nonfisik (komponen input), proses manajemen keluarga (permasalahan keluarga dan mekanisme penanggulangannya) dan terpenuhinya kebutuhan fisik dan psiko-sosial (Cahyaningtyas, Tenrisana, \& Triana, 2016). Dari pendekatan sistem ini, berarti bahwa ketahanan keluarga merupakan kemampuan keluarga dalam memecahkan masalahnya dengan menggunakan sumber daya yang dimiliki.

Keluarga dapat memiliki tingkat ketahanan keluarga yang baik apabila sudah memenuhi aspek-aspek berikut ini; 1) ketahanan fisik yaitu terpenuhinya kebutuhan pangan, sandang, perumahan, pendidikan dan kesehatan; 2) ketahanan sosial yaitu berorientasi pada nilai agama dan komitmen keluarga tinggi; 3) ketahanan psikologis meliputi kemampuan penanggulangan masalah non fisik, pengendalian emosi secara positif, konsep diri positif dan kepedulian suami terhadap istri.

Dalam membangun ketahanan keluarga dan kesejahteraan keluarga terdapat faktor pendukung, diantaranya kesiapan untuk melakukan perkawinan, keberfungsian, pemenuhan tugas, pengelolaan sumber daya, pengelolaan stress, pencegahan dan prediksi kerentanan, dan peningkatan kelentingan keluarga (Sunarti, 2018). Faktor-faktor ketahanan keluarga ini juga bisa menjadi sebuah prasyarat dalam membentuk ketahanan keluarga, salah satunya adalah kesiapan untuk melakukan perkawinan.

Ciri-ciri dari ketahanan keluarga secara garis besar adalah sikap melayani, keakraban pasangan, orang tua yang mengajari anaknya, anak-anak yang menghormati orang tuanya, jiwa altruism antar anggota keluarga, pemeliharaan hubungan anggota keluarga, lingkungan positif yang tercipta dalam suatu keluarga, dll (Puspitawati, Herawati, \& Sarma, 2018). Orientasi ketahanan keluarga dilihat berdasarkan keyakinan bahwa semua keluarga memiliki kekuatan dan potensi yang dapat dikembangkan untuk menjadi faktor perlindungan dan pemulihan keluarga guna mengamankan sumber daya serta menumbuhkan ketahanan keluarga (Black \& Lobo, 2008).
Dalam membangun ketahanan keluarga, pasti banyak yang menjelaskan tentang ciri-ciri ketahanan keluarga, di Indonesia sendiri mengacu pada indikator yang tertera dalam peraturan menteri PPPA Nomor 6 Tahun 2013 tentang pelaksanaan pembangunan keluarga terdapat 5 dimensi yang menjadi sebuah indikator ketahanan keluarga, diantaranya; 1) landasan legalitas dan keutuhan keluarga yang terdiri dari 3 variabel (landasan legalitas, keutuhan keluarga, kemitraan gender); 2) ketahanan fisik yang terdiri dari 3 variabel (kecukupan pangan dan gizi, kesehatan keluarga, ketersediaan lokasi tetap untuk tidur); 3) ketahanan ekonomi, terdiri dari 4 variabel (tempat tinggal keluarga, pendapatan keluarga, pembiayaan pendidikan anak, jaminan keuangan keluarga); 4) ketahanan sosial-psikologis, terdiri dari 2 variabel (keharmonisan keluarga, kepatuhan terhadap hukum); 5) ketahanan sosial-budaya, terdiri dari 3 variabel (kepedulian sosial, keeratan sosial, ketaatan beragama).

Ketahanan keluarga yang dibangun dapat dipengaruhi tingkat pendidikan yang dimiliki oleh keluarga, karena dalam membangun sebuah ketahanan keluarga dibutuhkannya kemampuan untuk memecahkan masalah ketika ada ancaman didalam keluarganya, sehingga akan berpengaruh pada pengambilan keputusan. Jika seseoranng yang memiliki tingkat pendidikan yang baik maka ia bisa menggunakan kemampuannya dengan baik dan mempunyai pola pikir yang bisa memecahkan masalah dengan sangat baik.

Berdasarkan konsep-konsep mengenai ketahanan keluarga yang sudah dijelaskan, maka dapat disimpulkan bahwa ketahanan keluarga itu ialah kondisi dimana kebutuhan dasar dapat terpenuhi dan adanya kemampuan untuk bisa melindungi diri dari berbagai permasalahan yang mengancam keluarganya baik internal maupun eksternal, namun tidak hanya kemampuan untuk melindungi diri saja, tetapi juga bisa memecahkan masalah yang bisa datang dari mana saja.

Idealnya, untuk membetuk ketahanan keluarga bisa dimulai dari individunya, yaitu kesiapan menikah. Pada dasarnya kesiapan menikah sama dengan kesiapan untuk berkeluarga, karena kesiapan menikah ialah suatu kondisi fisik maupun non fisik seorang individu untuk membangun keluarga dengan segala dinamika yang ada agar tujuannya tercapai. Kesiapan menikah menjadi sebuah faktor utama ketika seseorang memutuskan untuk melakukan perkawinan, karena jika seseorang sudah menikah 


\begin{tabular}{|c|c|c|c|c|}
\hline $\begin{array}{c}\text { Prosiding Penelitian \& } \\
\begin{array}{c}\text { Pengabdian Kepada } \\
\text { Masyarakat }\end{array}\end{array}$ & $\begin{array}{c}\text { e ISSN : 2581-1126 } \\
\text { p ISSN : 2442-448X }\end{array}$ & Vol 7, No: 1 & Hal: $90-99$ & April 2020 \\
\hline
\end{tabular}

maka keberfungsian keluarganya akan semakin baik.

Ketahanan keluarga tercipta jika kesiapan menikah semakin matang. Jika merujuk pada konsep dari ketahanan keluarga yang berarti kondisi stabil yang dapat diciptakan oleh sebuah keluarga maka, kesiapan menikah yang harus dimiliki oleh seseorang sebelum melakukan perkawinan adalah kesiapan yang meliputi spiritual, emosi, sosial, financial, fisik, peran, seksual dan usia (Cahyaningtyas, Tenrisana, \& Triana, 2016). Sebab, kesiapan-kesiapan tersebut akan mempengaruhi ketahanan keluarga yang akan dibentuk. Jika seseorang sudah memiliki kesiapan menikah dengan baik maka ketahanan keluarga akan mudah tercapai.

\section{Hasil dan Pembahasan}

Perkawinan usia muda di I ndonesia masih menjadi sebuah polemik, karena melihat dari data yang ada disetiap tahunnya angka perkawinan usia muda ini terus meningkat walaupun tidak tinggi. Data Badan Pusat Statistik (BPS) menyatakan bahwa 1 dari 4 anak perempuan di Indonesia telah melakukan perkawinan pada umur dibawah 18 tahun pada 2008 sampai 2015. Sudah tercatat bahwa sekitar 1.348.886 anak perempuan yang melakukan perkawinan dibawah usia 18 tahun pada 2012. Hal ini menunjukkan bahwa sekitar 300.000 anak perempuan yang telah kawin dibawah usia 16 tahun (Sunarti, 2018).

Data lainnya memiliki perbedaan dengan BPS, yaitu data SDKI menunjukkan bahwa $17 \%$ anak perempuan yang berada pada prevalensi usia 20-24 tahun sudah kawin sebelum usia 18 tahun, yang berarti hal ini digolongakan sebagai perkawinan anak. data dari SUSENAS pada tahun 2012, setidaknya ada $25 \%$ perempuan pada prevalensi usia 20-24 tahun yang telah melakukan perkawinan pada usia dibawah 18 tahun atau perkawinan anak.

\footnotetext{
Adanya permasalahan mengenai perkawinan usia muda yang masih terjadi di Indonesia, maka tidak menutup kemungkinan bahwa adanya perceraian yang diakibatkan dari adanya perkawinan muda ini. Jika kita merujuk kepada salah satu prasyarat ketahanan keluarga yang menyatakan bahwa kesiapan menikah menjadi salah satu syarat untuk bisa membangun ketahanan keluarga, maka tidak heran apabila tingkat perceraian di Indonesia menjadi tinggi karena masih banyaknya perkawinan muda yang terjadi di Indonesia.
}

Indonesia merupakan salah satu negara yang menyumbang angka perceraian yang tinggi. Misalnya kasus yang terjadi di Kabupaten Mojokerto, dilansir dari detik.com menjelaskan bahwa kasus perkawinan usia muda yang terjadi di Kabupaten Mojokerto cukup memprihatinkan. Dalam kurun waktu J anuari-Agustus 2019 tercatat ada 90 kasus perkawinan anak dibawah umur yang dilakukan pada umur 16 tahun untuk perempuan dan dibawah 18 tahun untuk pria. Kemudian, perkawinan muda dilakukan karena terjadinya hamil diluar nikah sebanyak 52 kasus. Sementara, kasus perceraian yang terjadi sepanjang Agustus 2019 sebanyak 2.472 kasus dan tahun 2018 sebanyak 2.992 kasus. Ribuan kasus itu, paling banyak dilakukan oleh pasangan muda dengan rentang usia 20-30 tahun. Selain di Kabupaten Mojokerto, pengadilan Medan juga sudah menangani sekitar 308 kasus perceraian dini sepanjang tahun 2018.

Kasus-kasus perceraian dari hasil perkawinan muda ini dapat menjelaskan bahwa perkawinan muda di Indonesia sangat berpengaruh dalam ketahanan keluarga yang dibangun sehingga berujung pada perceraian muda. Ketahanan keluarga yang dibangun menjadi keropos disebabkan oleh berbagai permasalahan atau faktor-faktor lainnya yang akhirnya berujung pada perceraian.

Jika merujuk pada konsep ketahanan keluarga yang menjelaskan bahwa didalam suatu keluarga perlu adanya kemampuan untuk menyelesaikan berbagai permasalahan dan ancaman yang dihadapi baik itu dari dalam maupun dari luar, maka ketahanan keluarga yang dibangun dari perkawinan muda ini belum mencapai konsep dari ketahanan keluarga itu sendiri. Hal ini disebabkan karena mereka belum memiliki pengetahuan mengenai membangun sebuah rumah tangga. Apalagi, perkawinan muda ini mengharuskan mereka untuk berhenti sekolah sehingga pengetahuan yang dimiliki pun terbatas.

Prasayarat untuk membangun ketahanan keluarga sangat tergambarkan pada kasus perkawinan muda ini. Kebanyakan perkawinan muda yang dilakukan berbagai daerah belum memenuhi prasyarat tersebut salah satunya kesiapan menikah. Faktanya, seseorang melakukan perkawinan bukan atas dasar dirinya telah siap untuk menikah akan tetapi didasari oleh berbagai faktor perkawinan usia muda yang telah dijelaskan sebelumnya. Dari segi psikologisnya, seseorang yang sudah kawin diusia muda pada dasarnya belum memiliki kesiapan mental. Kondisi 


\begin{tabular}{|c|c|c|c|c|}
\hline $\begin{array}{c}\text { Prosiding Penelitian \& } \\
\begin{array}{c}\text { Pengabdian Kepada } \\
\text { Masyarakat }\end{array}\end{array}$ & $\begin{array}{c}\text { e ISSN : 2581-1126 } \\
\text { p ISSN : 2442-448X }\end{array}$ & Vol 7, No: 1 & Hal: $90-99$ & April 2020 \\
\hline
\end{tabular}

emosionalnya yang masih mendominasi tentu akan mempengaruhinya dalam membangun ketahanan keluarga. Sehingga, menyebabkan perkawinan usia muda tidak berjalan dengan harmonis.

Selain itu, pasangan yang melakukan perkawinan dini ini hanya mengutamakan kesiapan fisiknya saja, tanpa memperhatikan kesiapan secara sosial, spiritual, emosional dan ekonomi. Maka, sudah pasti seseorang yang kawin muda belum siap untuk menanggung resiko dan konsekuensi untuk ke depannya. Sehingga tidak adanya visi ataupun tujuan dalam membangun rumah tangganya. Kesiapan fisik berarti juga belum siap untuk memikul beban menjadi orang tua.

Ketahanan keluarga juga tidak dapat dicapai apabila pasangan suami istri tidak paham atau tidak mengerti apa perannya dalam membangun ketahanan keluarga. Sebagaimana yang telah dijelaskan sebelumnya bahwa salah satu faktor pendukung ketahanan keluarga adalah pemenuhan tugas dalam rumah tangga. Merujuk pada teori struktural-fungsional, berarti bahwa seseorang yang melakukan perkawinan muda berarti belum berhasil dalam membangun sebuah keluarga. Karena, mereka belum paham apa peran serta fungsi mereka dalam keluarganya. Hal ini dibuktikan dengan pernyataan dari seorang istri yang kawin muda menyatakan bahwa dirinya belum paham mengenai tugas yang akan ia emban dan tidak sanggup untuk mengerjakannya.

Perkawinan muda tentu saja akan berpengaruh pada ketahanan keluarga, karena mereka perlu mempunyai kemmampuan resiliensi agar bisa memenuhi kebutuhan dasarnya seperti kebutuhan sandang, pangan dan papan. Akan tetapi, yang terjadi adalah pasangan yang telah memutuskan untuk melakukan perkawinan muda tentunya masih banyak yang belum mampu dalam memenuhi kebutuhan dasarnya. J ika merujuk pada Peraturan Menteri PPPA Nomor 6 Tahun 2013 tentang Pelaksanaan Pembangunan Keluarga, yang menyebutkan bahwa konsep ketahanan keluarga salah satunya adalah ketahanan ekonomi. Salah satu konsep ini dapat kita analisis untuk melihat kondisi keluarga dari pasangan yang kawin muda.

Ketahanan ekonomi dapat digambarkan ketika kemampuan keluarga dalam memenuhi kebutuhannya demi bisa melangsungkan kehidupannya dengan nyaman dan berkesinambungan. Kehidupan yang nyaman berarti memiliki rumah yang layak dan berkesinambungan berarti keluarga tersebut selalu memiliki pendapatan dalam jumlah yang mencukupi semua kebutuhan hidupnya. Namun, jika melihat realitanya pembangunan keluarga dan ketahanan keluarga yang menjadi masalah dan tantangan khususnya bagi pasangan yang telah menikah muda.

Jika ditelaah, ketahanan keluarga yang dibangun sangat mudah keropos. Salah satunya ketahanan ekonomi yang merupakan bagian dari ketahanan keluarga. Pasangan yang telah kawin muda banyak yang belum bisa memenuhi kebutuhan hidup yang berkesinambungan, dalam hal ini berarti pendapatan. Seperti yang terjadi dibeberapa daerah contohnya di Sukabumi. Perempuan yang telah melakukan perkawinan usia muda menyatakan bahwa ekonomi keluarganya tidak mencukupi untuk memenuhi kebutuhan dasarnya. Hal ini dikarenakan usia mereka yang masih sangat muda menyebabkan pendapatan yang mereka terima tidak selalu memenuhi kebutuhan hidupnya.

Ketahanan ekonomi yang tidak dapat dipenuhi sebagai akibat dari terbatasnya pendidikan yang dimiliki oleh pasangan suami dan istrinya. Sehingga menyebabkan belum adanya pekerjaan yang menjamin dapat memenuhi kebutuhan dasarnya. Dengan ketidakmampuan dalam memenuhi kebutuhan rumah tangganya, tentu akan memunculkan konflik didalam rumah tangga sehingga akan membuat konsep dari ketahanan keluarga itu akan runtuh lagi, yaitu ketahanan sosial-psikologis. Pasangan yang menikah diusia muda tentu belum memiliki emosi yang stabil apalagi dalam memecahkan masalah. Maka, apabila hal ini terjadi maka ketahanan keluarga yang dibangun belum kuat.

Ketahanan ekonomi ini menjadi sebuah faktor utama yang menyebabkan ketahanan keluarga dari perkawinan usia muda menjadi roboh. Jika ada salah satu konsep ketahanan keluarga yang tidak dapat dipenuhi, tentunya tidak akan terciptanya berpengaruh ke konsep ketahanan keluarga yang lain hingga menyebabkan tidak harmonisnya hubungan sebuah keluarga. Perkawinan muda berpengaruh terhadap ketahanan keluarga agar meningkatkan taraf kehidupan dan meningkatkan kesejahteraan hidupnya. Namun, apabila kenyataannya adalah kondisi yang tercipta tidak membuat nyaman, aman, tentram dan tidak terpenuhi ketahanan fisik-ekonomi, sosial dan psikologis maka ketahanan keluarga yang dibangun belum mencapai kondisi yang stabil. 


\begin{tabular}{|c|c|c|c|c|}
\hline $\begin{array}{c}\text { Prosiding Penelitian \& } \\
\begin{array}{c}\text { Pengabdian Kepada } \\
\text { Masyarakat }\end{array}\end{array}$ & $\begin{array}{c}\text { e ISSN : 2581-1126 } \\
\text { p ISSN : 2442-448X }\end{array}$ & Vol 7, No: 1 & Hal: $90-99$ & April 2020 \\
\hline
\end{tabular}

\section{Simpulan}

Perkawinan usia muda masih menjadi sebuah polemik di Indonesia karena rentan terjadi perceraian akibat belum stabil kondisi psikologis yang dimiliki oleh pasangan muda tersebut.

Sehingga, perkawinan usia muda ini berdampak pada ketahanan keluarga yang dibangun. Usia muda masih memiliki kerentanan dalam sisi psikologisnya, emosi yang ketidaksiapan mental yang dimiliki dan tingkat emosi yang masih tinggi menyebabkan ketahanan keluarga menjadi keropos. Selain itu, jika melihat fakta lapangannya banyak diantara pasangan muda ini melakukan perkawinan tidak atas dasar prasyarat ketahanan keluarga itu sendiri, melainkan hanya kesiapan dari segi fisiknya saja. Padahal kesiapan menikah berarti adalah kesiapan untuk membangun keluarga yang tentunya hal ini dijadikan sebagai pondasi untuk membangun ketahanan keluarga.

Perkawinan usia muda dilakukan setelah memutuskan untuk berhenti sekolah maka pendidikan maupun pengetahuan yang dimiliki terbatas. Khususnya mengenai dampak-dampak perkawinan muda ini. Hal ini akan berpengaruh terhadap konsep ketahanan keluarga yaitu ketahanan ekonomi. Putus sekolah akan menyebabkan keluarga tersebut tidak memiliki pendapatan yang cukup untuk memenuhi kebutuhan hidupnya sehingga tidak tercapainya ketahanan ekonomi yang berkesinambungan.

Kasus perkawinan muda di Indonesia ini memang perlu segera diatasi melalui pemberian edukasi terhadap murid-murid yang bersekolah agar memahami betul dampak-dampak yang akan didapatkan ketika melakukan perkawinan muda. Selain perkawinan muda perlu juga adanya edukasi tentang bagaimana membangun ketahanan keluarga agar menghasilkan keluarga yang berkualitas agar tidak ada lagi yang memaknai perkawinan hanya sebatas memiliki anak saja dan juga memiliki kesiapan menikah yang sangat matang, tidak hanya memiliki kesiapan secara fisik saja, aspek-aspek yang lain perlu diperhatikan dengan tujuan menghasilkan keluarga yang sejahtera.

\section{Ucapan Terima Kasih}

Dengan selesainya penulisan ini, penulis mengucapkan terima kasih yang sedalamdalamnya kepada dosen IImu Kesejahteraan Sosial Universitas Padjadjaran khususnya ibu Nunung Nurwati yang telah membantu penulis dalam menyelesaikan artikel ini. Tidak lupa juga penulis ucapkan terima kasih untuk kedua orang tua, teman-teman, dan semua yang telah memberikan dukungan secara moril dan materil. Semoga artikel ini memberikan manfaat untuk penulis dan pembaca.

\section{Daftar Pustaka}

Afif. (2020, April 18). Pernikahan Dini Rentan Bercerai. Retrieved from Merdeka.com: https://www.merdeka.com/peristiwa/pern ikahan-dini-rentan-bercerai.html

Al-Mighwar, M. (2006). Psikologi Remaja. Bandung: Penerbit Pustaka Setia.

Arimurti, I., \& Nurmala, I. (2017). ANALISIS PENGETAHUAN PEREMPUAN TERHADAP PERILAKU MELAKUKAN PERNIKAHAN USIA DINI DI KECAMATAN WONOSARI KABUPATEN BONDOWOSO. The Indonesian Journal of Public Health, 1-2.

Black, K., \& Lobo, M. (2008). A conceptual review of family resilience factors. Journal of Family Nursing, 33-55.

Burns, A. A., Lovich, R., Maxwell, J ., \& dkk. (2016). Pemberdayaan wanita dalam bidang kesehatan. Yogyakarta: Yayasan Essentia Medica Andi.

Cahyaningtyas, A., Tenrisana, A. A., \& Triana, D. (2016). Pembangunan Ketahanan Keluarga. Jakarta: Kementerian

Pemberdayaan Perempuan dan Perlindungan Anak.

Djamilah, R. K. (2014). Dampak Perkawinan Anak di Indonesia. Jurnal Studi Pemuda, 2.

Hanum, Y., \& Tukiman. (2015). DAMPAK PERNIKAHAN DINI TERHADAP KESEHATAN ALAT REPRODUKSI WANITA. Jurnal Keluarga Sehat Sejahtera, 36.

Harsono, F. H. (2020, April 18). Akibat Perkawinan Anak, Cerai di Usia Muda Tak Terhindarkan. Retrieved from liputan6.com: https://www.liputan6.com/health/read/35 75357/akibat-perkawinan-anak-cerai-diusia-muda-tak-terhindarkan

Kangsaputra, L. S. (2020, April 18). Psikolog Ungkap Penyebab Meningkatnya Perceraian Dini di Indonesia. Retrieved from lifestyle.okezone.com: https://lifestyle.okezone.com/read/2018/1 2/17/196/1992354/psikolog-ungkap- 


\begin{tabular}{|c|c|c|c|c|}
\hline $\begin{array}{c}\text { Prosiding Penelitian \& } \\
\begin{array}{c}\text { Pengabdian Kepada } \\
\text { Masyarakat }\end{array}\end{array}$ & $\begin{array}{c}\text { e ISSN : 2581-1126 } \\
\text { p ISSN : 2442-448X }\end{array}$ & Vol 7, No: 1 & Hal: 90 - 99 & April 2020 \\
\hline
\end{tabular}

penyebab-meningkatnya-perceraian-dinidi-indonesia

Kumalasari, A. (2020, 18 April). Pernikahan Dini Pemicu Angka Perceraian Meningkat. Retrieved from Kompasiana.com: https://www.kompasiana.com/anggikuma lasari/5dfdc70dd541df1b7a3e71e3/pernik ahan-dini-pemicu-angka-perceraianmeningkat?page $=1$

Lestari, R. P. (-). Hubungan antara Pernikahan Usia Remaja Dengan Ketahanan Keluarga. Jurnal Kesejahtraan Keluarga dan Pendidikan, 85-87.

Moleong, L. J. (2003). Metodologi Penelitian Kualitatif. Bandung: Remaja Rosdakarya.

Nasrin, S. O., \& Rahman, K. M. (2012). Factors Affecting Early Marriage and Early Conception of Women: A case of slum areas in Rajshahi City, Bangladesh. International Journal of Sociology and Anthropology, 54-62.

Puspitawati, H., Azizah, Y., Mulyana, A., \& Rahmah, A. F. (2019). RELASI GENDER, KETAHANAN KELUARGA DAN KUALITAS PERNIKAHAN PADA KELUARGA NELAYAN DAN BURUN TANI "BRONDOL" BAWANG
MERAH. Jurnal IImu Keluarga dan Konsumen, 1-3.

Puspitawati, H., Herawati, T., \& Sarma, M. (2018). RELIABILITAS DAN VALIDITAS INDIKATOR KETAHANAN KELUARGA. Jurnal Kependudukan Indonesia, 1-14.

Sahrizal, N., Handayani, P. S., Chamami, A., \& dkk. (2020). Pencegahan Perkawinan Anak: Percepatan yang Tidak Bisa Ditunda. J akarta: PUSKAPA.

Sunarti, E. (2018). Pernikahan dan Ketahanan Keluarga. unknown, 1-6.

Tyas, F. P., \& Herawati, T. (2017). KUALITAS PERNIKAHAN DAN KESEJ AHTERAAN KELUARGA MENENTUKAN KUALITAS LINGKUNGAN PENGASUHAN ANAK PADA PASANGAN YANG MENIKAH USIA MUDA. Jurnal IImu Keluarga dan Konsumen, 1-3.

Unknown. (2020, April 18). BKKBN: Pernikahan Dini Picu Tingginya Angka Perceraian. Retrieved from Beritasatu: https://www.beritasatu.com/nasional/521 344-bkkbn-pernikahan-dini-picutingginya-angka-perceraian 